\title{
Focus on the User: Front Matter in Slovenian Dictionaries
}

\author{
Marjeta Vrbinc, Department of English, Faculty of Arts, University of \\ Ljubljana, Ljubljana, Slovenia (marjeta.vrbinc@ff.uni-lj.si) \\ and \\ Alenka Vrbinc, Faculty of Economics, University of Ljubljana, Ljubljana, \\ Slovenia (alenka.vrbinc@ef.uni-lj.si)
}

\begin{abstract}
This article focuses on the front matter texts of three Slovenian monolingual dictionaries: Dictionary of Standard Slovenian, Dictionary of Slovenian Synonyms and Dictionary of Legal Terminology. We asked thirty-two MA students of English at the University of Ljubljana to read the front matter texts and comment on intelligibility of the text, usefulness of the text from the point of view of intended users, language used in the text, examples provided to illustrate the theoretical explanation and length of the text as a whole. According to the majority of the students, the front matter texts of all three dictionaries use terminology known only to linguists. They also frequently comment on the length and complexity of sentences, information overload and the indirect inclusion of examples that illustrate the theory. Apart from being critical of the texts, they point out what they like (the front matter texts in all three dictionaries are well-structured, as they are divided into sections and subsections, thus enabling easy access to relevant information within the text) and give proposals for improvement of the text (rearrangement of various sections, the use of Slovenian terms instead of borrowings, the use of paraphrases instead of terms, shorter sentences and simpler syntax).
\end{abstract}

Keywords: FRONT MATTER TEXTS, USER GUIDE, GRAPHIC PRESENTATION OF ENTRIES, INTELLIGIBILITY, USEFULNESS, EXAMPLES, LINGUISTIC TERMS, SYNTAX

Opsomming: Fokus op die gebruiker: Voortekste in Sloweense woordeboeke. Hierdie artikel fokus op die voortekste van drie Sloweense eentalige woordeboeke: Woordeboek van Standaardsloweens, Woordeboek van Sloweense Sinonieme en Woordeboek van Regsterminologie. Twee en dertig MA-studente van Engels aan die Universiteit van Ljubljana is gevra om die voortekste te lees en kommentaar te lewer op die verstaanbaarheid van die teks, die bruikbaarheid van die teks vanuit die perspektief van die teikengebruikers, die taal wat in die teks gebruik word, die voorbeelde wat verskaf word om die teoretiese toeligting te illustreer en die lengte van die teks as geheel. Volgens die meerderheid studente word daar in die voortekste van al drie woordeboeke terminologie gebruik wat net aan taalkundiges bekend is. Hulle lewer ook dikwels kommentaar op die lengte en kompleksiteit van sinne, inligtingoorlading en die indirekte insluiting van voorbeelde wat die teorie illustreer. Buiten die kritiek wat hulle op die tekste lewer, dui hulle ook aan waarvan hulle hou (die voortekste in al drie woordeboeke is goed gestruktureer aangesien hulle verdeel is in afdelings en onderafdelings, wat sodoende maklike toegang tot relevante inligting binne die teks 
moontlik maak) en maak hulle voorstelle vir die verbetering van die tekste (herorganisering van verskeie onderafdelings, die gebruik van Sloweense terme in plaas van ontlenings, die gebruik van parafrases in plaas van terme, korter sinne en eenvoudiger sintaksis).

Sleutelwoorde: VOORTEKSTE, GEBRUIKERSGIDS, GRAFIESE VOORSTELLING VAN INSKRYWINGS, VERSTAANBAARHEID, BRUIKBAARHEID, VOORBEELDE, LINGUISTIESE TERME, SINTAKSIS

\section{Front matter: Some theoretical considerations}

It is a widely held perception that dictionaries are repositories of words, but they may also contain pictures, symbols, audio files, etc. When users take a dictionary off a shelf or access it on their computers, they do it mostly to look up a word or word combination. A dictionary is the product of any lexicographic work, and the word 'dictionary' itself is powerful, since it implies authority, scholarship and precision (Landau 2001: 6). But what actually is a dictionary? It is not only a reference resource consisting of "an alphabetical list of words with their meanings and parts of speech, and often a guide to accepted pronunciation and syllabification, irregular inflections of words, derived words of different parts of speech, and etymologies" (sense 1.a) or "a similar reference work giving equivalent words in two or more languages" (sense 1.b), as defined in Collins English Dictionary, since these definitions focus only on the A-Z section of the dictionary (if the language treated in the dictionary uses an A-Z alphabet), which is by no means the only element of the dictionary structure (cf. also Bergenholtz's definitions of 'dictionary' in Bergenholtz 2012: 30). Admittedly, from the perspective of an average user, this is the most important part, the (only) part they actually consult. However, from the metalexicographic perspective, the dictionary structure is much more complex, as it refers to the interrelation of dictionary components. The information provided by a dictionary is far from being simple in nature, and if lexicographers want the information included in a dictionary to be comprehensible to users, it should be presented according to certain structural principles. Thus, the dictionary structure includes megastructure, microstructure, access structure, distribution structure and cross-reference structure (Hartmann 2001: 57-62; Svensén 2009: 77-82). The megastructure is the overall framework of the component parts of a dictionary and consists of the macrostructure and the outside matter. The elements of the outside matter are classified depending on their physical position in the dictionary, considering the $\mathrm{A}-\mathrm{Z}$ section as the central part of the dictionary: the front matter precedes the $A-Z$ section; the middle matter contains items inserted in the $A-Z$ section without forming a constituent part of it; and the back matter follows the A-Z section. The front matter may include the title page, the copyright page and imprint, acknowledgements, the foreword or preface, the table of contents, the list of contributors, the list of abbreviations, labels and codes used in the text and/or illustrations, the pronunciation key, 
the user's guide and dictionary grammar. It may also offer essays on certain aspects of language, such as the history of the language, a feature which largely depends on the market at which it is aimed (Hartmann and James 1998: 60; Atkins and Rundell 2008: 176-177). Since this article concentrates on front matter texts only, other elements of the megastructure will not be the focus of attention.

Taking account of the variety of text types or genres a dictionary includes, the most obvious difference is between the text in the outside matter and that of the A-Z section (Bergenholtz, Tarp and Wiegand 1999: 1763). As mentioned above, the division of the outside matter is based on the position of texts in a printed dictionary. Similar to printed dictionaries, online dictionaries also contain a number of outer texts. As Müller-Spitzer (2013: 374) maintains, the term outer features is more appropriate when referring to outside matter in electronic dictionaries, since the elements in the outer domain of online dictionaries do not all belong to the category of text (Klosa and Gouws 2015: 148). In online dictionaries, the outer features, and the user guide in particular, are as important as in printed dictionaries or even more so, since online dictionaries offer a much greater variety of search options than printed dictionaries, and these options have to be explicated if users are to make full use of them (Nielsen 2006: 11). Users also have different expectations when consulting electronic dictionaries as there is a whole range of standard web or mobile practices that are required or that affect the user experience.

In the study whose findings are presented in this article, the focus is on the utility of front matter texts to dictionary users. Front matter texts include one very specific part, i.e., the user guide, which is second only to the A-Z section in terms of importance of the texts in a dictionary (Kirkpatrick 1989; Landau 2001: 149; Nielsen 2006: 1) and is therefore absolutely essential if lexicographers want the dictionary to be an effective tool (Nielsen 2005: 137). As Kirkpatrick (1989: 754) writes in her insightful article on user guides, "[t]he general assumption is that no-one bothers to read the front matter of dictionaries", an assumption, confirmed by the students participating in our small-scale study. She also points out that dictionary users are reluctant to consult the front matter (even less the back matter). This lack of interest in the front matter is at least partly related to the popular belief that all dictionaries are similar in structure, and no specific information on their use is necessary (Kirkpatrick 1989: 754; Nielsen 2006: 7). The types of information that lexicographers should include in a user guide depend on the dictionary compiled and vary from dictionary to dictionary. Nielsen (1995: 170-171) proposes four basic issues to be addressed in a user guide: type of information in specific components; the systematization of this information (grouping, placement and arrangement); the interrelation of information in individual components; and the quickest and easiest access to the information required.

The user guide should be written very carefully by the lexicographer the sender of the message - who should take into account the linguistic, factual 
and cultural competences of the target user - the receiver of the message who is the primary beneficiary (Nielsen 2006: 11). If it is written for the benefit of lexicographers or academics, priority is given to detail being presented very scientifically, thus adopting a compiler perspective rather than a user perspective. In this case, it is highly unlikely that it would benefit the real user, which means that the quality of information is low (Nielsen 2006: 11).

The aim of our study was not to ask users whether they read the user guides of the dictionaries they consult or whether they have ever read a user guide, but to ask them to read user guides and comment on various aspects of the text. For this purpose, three Slovenian monolingual dictionaries were selected: Slovar slovenskega knjižnega jezika, 2nd edition (Dictionary of Standard Slovenian, hereafter referred to as DSS2), Sinonimni slovar slovenskega jezika (Dictionary of Slovenian Synonyms, hereafter referred to as DSSyn) and Pravni terminološki slovar (Dictionary of Legal Terminology, hereafter referred to as DLT). These three dictionaries belong to different categories according to a dictionary typology: DSS2 is a general monolingual dictionary; the DSSyn is a specialized dictionary dealing with a specific area of language, i.e. synonyms; and the DLT is a terminological dictionary treating the terminology of a special subject field. All three dictionaries were originally conceived and first published as printed dictionaries. Later, they were transferred to an online environment with very minor changes and can now be accessed free of charge via the Fran portal (https://fran.si/). Regrettably, only very few existing online dictionaries really use the technical possibilities of the electronic medium to full potential, whether in the conception and preparation of dictionaries or in access to and presentation of the data therein (Fuertes-Olivera and Bergenholtz 2011: 1). Since the emergence of online lexicography has heralded a new culture in dictionary use, lexicographers should take cognizance of this new culture (Gouws 2018: 233). However, the dictionaries included in our study do not make use of all the possibilities offered by the online environment. All three dictionaries under consideration are intended for native speakers of Slovenian; DSS2 and DSSyn can be used for decoding purposes, i.e., they can be consulted for comprehension when reading texts, as well as for encoding purposes, i.e., when writing or editing texts, whereas the DLT is aimed at decoding as well as acquiring knowledge about legal terms.

\section{Front matter texts in the dictionaries studied}

\subsection{Dictionary of Standard Slovenian}

The first edition of the DSS was initially published in five volumes over a period of 21 years (from 1970 to 1991). Later, a one-volume publication came out in 1994 with minor corrections (typos and other technical corrections). Since 2000, the Dictionary has been available online with free access. The second edition, whose front matter text is investigated in our study, came out in 2014 and is an 
only partially revised version of the first edition.

The front matter of DSS2 consists of as many as 63 pages and includes the following: the copyright page and imprint; list of editors and lexicographers; Prefaces: Preface to the Second Edition, Preface to the First Edition, Preface to the Single-Volume Edition. All these parts together comprise 22 pages. Then follows the part entitled Introduction, which is subdivided into the following eight sections with subsections (41 pages altogether):

- Some General Facts about the Dictionary (+ two subsections)

- Type of the Dictionary (+ two subsections)

- Structure of the Dictionary (+ two subsections)

- Semantic Part of the Dictionary Entry (+ five subsections)

- Grammatical Information in the Dictionary Entry (+ six subsections)

- Typography

- List of abbreviations and labels

- Miscellaneous

The section entitled Some General Facts about the Dictionary gives an overview of the history of Slovenian lexicography, including the institutions where lexicographic work was carried out in the past. This lexicographic tradition served as a basis for the preparation of the first edition of the DSS. Tribute is paid to the first Slovenian lexicographers and to individuals who were the driving force behind the creation of the DSS.

The section Type of the Dictionary does not pertain to dictionary typology but presents the contents of the dictionary and provides information on the material not included in the dictionary, on the aims of the dictionary as well as on its scope and normativity. Very detailed data on the number of lemmata and sublemmata included in the dictionary are provided. DSS2 contains 97,669 lemmata and 14,181 secondary lemmata (a total of 111,850) and 157,978 senses and subsenses. The subsection Material Used for the Compilation of the Dictionary includes information on the sources and explains methods employed in the collection of material.

In the section Structure of the Dictionary, the macrostructure of the dictionary is explained and information on sublemmata and cross-references is given, which is followed by a detailed presentation of the structure of the dictionary entry.

The section Semantic Part of the Dictionary Entry focuses on the dictionary definitions ranging from the types of definitions to the characteristics and peculiarities of definitions. The arrangement of senses within the entry is explained in detail, followed by the presentation and arrangement of the illustrative material. At the end of the entry, two sections may be included, i.e., the phraseological section and the terminological section. The phraseological section includes various categories of phraseological units, whereas the terminological section contains terms and terminological units. The subsection Labels explains what a label is, how a user can interpret the scope of labels depending 
on their position in the entry, what types of labels are used in the dictionary and what the peculiarities of labels are. Labels are subdivided into grammatical, semantic, terminological, stylistic, expressive, temporal and frequency labels and special normative labels; each category is thoroughly explained.

The section Grammatical Information in the Dictionary Entry provides instructions on how to interpret the first part of the dictionary entry up to and including the part-of-speech label. Then follow some orthographic considerations, phonological rules and the explanation of data presented in square brackets as well as very detailed information on stress by parts of speech.

The section Typography discusses typographical devices used in the dictionary, such as different fonts and font sizes, bold type, semibold type and italics. The punctuation marks used in the entries are fully explained and so are some special symbols, such as two slashes $(/ /)$, one slash $(/)$, $\operatorname{dot}(\bullet)$ and diamond (•).

The section List of abbreviations and labels enumerates part-of-speech labels, labels belonging to all categories of labels as well as other abbreviations used in the dictionary, such as itd. ('etc.'), $\check{z}$ ('f' - feminine gender), os. ('person'). The list is extensive and occupies two two-column pages.

The section Miscellaneous is subdivided into two subsections: one explains that the dictionary is alphabetically arranged and that foreign diacritical marks exert no influence on the alphabetical arrangement; the other one deals with special signs.

\subsection{Dictionary of Slovenian Synonyms}

The printed edition of the DSSyn starts with a two-page graphic presentation of the entries in the dictionary. Then follow the title page, the copyright page and imprint, the two-page Foreword and the Structure of the Dictionary of Slovenian Synonyms, which spans 23 pages. The total number of pages of the front matter texts amounts to 29. The same content can be found in the front matter of the online edition, the only exceptions being a much shorter graphic presentation of the entry and a text entitled About the Online Edition of the Dictionary of Slovenian Synonyms, which will be discussed separately.

The section Structure of the Dictionary of Slovenian Synonyms, which is of the utmost importance for the dictionary user, is subdivided into nine subsections, some being further subdivided into subsubsections. First, the content of the DSSyn is dealt with: what synonyms are, explanation of the common semantic meaning of a synonym set, semantic peculiarities of individual synonyms, (co-)hyponyms. Next, the material as well as the lexical and semantic criteria used in the compilation of the DSSyn are discussed at great length. Then follows the section entitled Basic Arrangement of the Dictionary Text, where types and various sections of the entry are explained clearly and concisely. The section Dominant Dictionary Entry: Parts of the Entry Regarding Form and Content gives a thorough presentation of the entry itself by discussing the lemma and the data on the 
lemma itself, the synonym section and the role of individual components of the synonym section. Two further sections deal with the semantic individuality of synonyms in the synonym set and labelling of synonyms. The front matter concludes with a brief discussion of different parts of speech in synonymy and a final section dealing with the Slovenian lexicographic tradition and the DSSyn.

The section About the Online Edition of the Dictionary of Slovenian Synonyms included in the online edition only is aimed at explaining the use of possibilities offered by the online environment in comparison with the printed edition of the dictionary. It focuses on the dominant dictionary entry and explains how individual component elements of this type of entry are presented in the online edition. The online edition includes a special icon; by clicking on this icon, the user is shown information on the placing of a certain noun into the specific conceptual group.

\subsection{Dictionary of Legal Terminology}

The DLT contains front matter of 19 pages: the copyright page and imprint; From Reviews of the Dictionary; Foreword; Slovenian Legal Terminology with two subsections, i.e., Development of the Slovenian Legal Terminology and Contemporary Slovenian Legal Terminology; About the Compilation of the Dictionary; Structure of the Dictionary; Abbreviations and Symbols. The section Structure of the Dictionary is of the utmost importance for the user, especially from the perspective of dictionary use. This section is further subdivided into several subsections: Type of Dictionary and Basic Information about the Dictionary (with a list of subfields, from which terms are included in the dictionary); Target Dictionary Users; Methodology; Time Span; Normativity; Structure of a Dictionary Entry; Definition; Explanation; Synonyms; and Cross-references. This central section consists of seven pages of text accompanied by a number of examples taken from the dictionary.

\section{Methods of obtaining users' views}

Generally speaking, front matter and user guides in particular are intended for the user. Since the focus of our study is on the user, we carried out a small-scale research study among first-year MA students of English at the Department of English, Faculty of Arts, University of Ljubljana. The study was carried out within the framework of the course on lexicography as part of the students' home assignments. Since the front matter texts of the selected dictionaries are very long, we initially planned to concentrate on the user guides within the front matter, but none of the dictionaries studied includes a section with a straightforward title, such as "User guide" or "How to use the dictionary". That is why we decided to take the entire front matter, excluding only Prefaces and Forewords, and we therefore use the term front matter text(s) rather than user guide(s). The front matter texts were subdivided into several parts of approxi- 
mately the same length, taking also the thematic component into consideration. Each student could choose which dictionary and which part of the front matter text to read.

The front matter text in DSS2 is the longest and was therefore subdivided into five parts. Four parts were read by three students and one part by four students, which means that sixteen students (including two non-native speakers) read the text. The front matter text in the DSSyn is shorter than that in DSS2 and was split into four parts. Each part was read by three students, i.e., twelve students altogether. The front matter text in the DLT is the shortest of all three front matter texts; that is why the text was divided into two and each part was read by two students, which means that four assignments were handed in. Altogether, thirty-two students participated in the study, two of them being non-native speakers of Slovenian; since the dictionaries investigated are intended for native speakers of Slovenian, the comments of these two students were excluded from the analysis. The comments and opinions of thirty students are presented and discussed in this article.

Even though the students were supposed to read only the selected segment of the front matter text, they were advised to refer to previous parts of the text if they came across unknown terms, since these terms could have been explained earlier in the text. They were asked to pay special attention to and comment on the following:

1. Intelligibility of the text;

2. Usefulness of the text from the point of view of intended users (what is useful, what is not useful);

3. Language used in the text (lexis including terminology and syntax);

4. Examples provided to illustrate the theoretical explanation (especially their presentation);

5. Length of the text as a whole.

They were also encouraged to make any critical comment that might cross their minds while reading the texts, express their opinion about the text as a whole and think of possible suggestions for the improvement of the text to make it more helpful.

\section{Users' views and comments}

\subsection{Dictionary of Standard Slovenian}

\subsubsection{Terminology and syntax}

Students reading the beginning of the front matter text think it is written in simple language and the terminology used is in accordance with the terminology taught and learnt in grammar school. One of the students says: "The language in the introduction is simple and intelligible. The author conveys a clear 
message and does not use any unnecessary or subjective descriptions." Several students point out that terminology used in the text is explained (e.g., the explanation of the term glava, the term referring to the first part of the dictionary entry up to and including the part-of-speech label). Similarly, students generally like the beginnings of each section, as the text systematically defines terms used in that particular section and a few general facts are explained.

As they progress through the text, students start to be more critical, especially about excess (detailed) information, which is of no practical use for the general user, and about the large number of terms from different areas of linguistics with which they are not familiar. According to the majority of the students reading different segments of DSS2's front matter text, the terminology used is known only to experts in the field of linguistics and is thus far too difficult and inappropriate for an average user (e.g., ekspiratorni naglas - expiratory accent). In their opinion, this is the main reason that it is a real struggle for the user to plough through the text. However, some students point out that there are cases where the use of terms cannot be avoided (e.g., the explanation of a complex classification of labels).

Students also frequently comment on the length and complexity of sentences, which they mostly find too long and too complex; consequently, they are difficult to process and understand. However, one student remarks that, although the sentences are quite long, Slovenians are used to long sentences. $\mathrm{He} / \mathrm{She}$ thinks that it is the abundant use of terminology that makes these long sentences difficult to comprehend.

One student clearly expresses his/her dissatisfaction with the style in which the entire text is written by saying that the text should be readily intelligible to all dictionary users, i.e., to linguists and non-linguists alike, but it seems that the information is given in a manner understandable only to linguists. He/she goes on commenting on the substantial number of (linguistic) terms and complexity of syntactical structures, which gives the impression that the lexicographers focus on the aesthetic value of the text rather than on coherence and intelligibility. Consequently, the cognitive effort needed to understand the text is unnecessarily much greater, which also results in the need for much more time to read the text. His/Her suggestion is to use short sentences and to repeat the same structures. He/She admits that the text would not be as artistically accomplished as it is. However, the text is not a work of art; on the contrary, its primary function is to provide instructions for the use of the dictionary. Therefore, the aesthetic side of the text is irrelevant, or in other words, functionality should be given priority.

\subsubsection{Amount of information}

Students mostly agree that the explanations found under various (sub)headings are too detailed, since an average user would not even bother to read the front matter text and would thus simply "ignore" a lot of information 
included in the dictionary. Information overload causes numerous problems, especially when reading the text for the first time; on second reading, the text is slightly easier to understand. One student gives an example from the section on the scope of labels used in the dictionary, where the lexicographers explain in great detail how the differing positions of the labels exert influence on their scope. Given the many possible combinations, the user needs to read the text several times to memorize all the details. On the other hand, one student claims that the wealth of information is beneficial to somebody dealing with the language or somebody interested in lexicography; therefore, it is better to have too much information (TMI). Although being generally critical of the inclusion of TMI, students point out that the front matter text is well-structured, as it is divided into numbered paragraphs; the paragraph numbers are used to refer to other parts of the text, thus enabling easy access to other relevant information within the text.

Students believe that several sections of the front matter text are not needed and would probably be skipped by most users seeking to retrieve only the basic information relating to the actual use of the dictionary. Examples of what students consider inessential sections include: Some General Facts about the Dictionary, which contains a comprehensive explanation about the history and compilation of the DSS; Characteristics of Definitions and Types of Definitions. According to students, these sections might be of interest to an expert rather than to an average user and could be left out without detriment to the user.

\subsubsection{Examples}

Some students express criticism of the examples. One of them points out that the examples are provided only "indirectly". What this student refers to is that only the lemma is given as an example. This means that the reader of the front matter text needs to look up that specific lemma in the A-Z section and find the part of the entry exemplifying the theory. In many instances, this process might be not only time-consuming and "extremely impractical" but also quite demanding. Another problem indicated by quite a few students is that the choice of examples is not always appropriate, since the lemmata given are words unknown to an average native speaker (e.g., bisus 'byssus', bantam 'bantam(weight)'), which causes additional problems because the user does not always know what an example illustrates. On the other hand, students point out that there are more than enough examples, but they are not helpful if the user does not look up the word in the A-Z section. They agree that it would be much better to have fewer examples and suggest including (at least part of) the entry, with a clear indication which part of the entry is referred to in the theoretical explanation. One student also says that, although examples provided are relevant, they are of little or no help if the reader does not understand the theoretical explanation, which, in turn, is much too scientific.

Generally, it can be claimed that the students like the examples, since these can help in understanding the theory. One student commenting on the 
explanation of labels says, for example, that the text contains short sentences and all labels are exemplified, which leads the user quickly to the desired information. The examples make it easier for the user to understand the message lexicographers are trying to convey. Students also noticed the typography of examples (i.e., italics), which they find useful, since it indicates clearly what is theory and what is the exemplification of the theory.

\subsubsection{Proposals for improvement of the text}

Students suggest the rearrangement of various sections in the front matter text. Sections that are absolutely essential for users to study if their look-up operations are to be effective, such as practical guidelines instructing the user how to use the dictionary, should be moved to the beginning of the front matter. Apart from that, they should be typographically distinguished from other sections of the front matter in order to immediately attract the user's attention. The students also propose the inclusion of a visual presentation of the dictionary entry with explanations of individual entry components, since they consider it useful and beneficial.

As for the use of linguistic terms, students prefer a Slovenian term to a foreign one (e.g., protipomenka instead of antonim 'antonym'). In the front matter text, many terms are explained, but there are still several terms that remain unexplained; to resolve this inconsistency, students speak in favour of a more consistent inclusion of explanations of terms. Another suggestion they make is to use paraphrases (e.g., 'the last sound of the word') rather than terms (e.g., izglasje). One of the students clearly states that the text is written far too scientifically; therefore, he/she suggests that if lexicographers believe so much terminology is necessary in the front matter text, it could prove helpful to compile a glossary of linguistic terms used in the front matter text with clear explanations of the concept behind the terms. The glossary, according to the student, should be part of the front matter.

\subsection{Dictionary of Slovenian Synonyms}

\subsubsection{Terminology and syntax}

Throughout the front matter text, very specific terminology is used; however, some students maintain that, despite this, the text is relatively comprehensible. Most of the terms are explained, and if the user/reader is interested in the topic and reads the text carefully and slowly, he/she can understand the gist of what the text is about. In some parts of the text, they found terms that are not explained and can be a "big mystery" for someone unfamiliar with linguistic terminology (e.g., denotative meaning). One student puts it nicely that the complexity of the lexis is "a hindrance to the average user as it encumbers the reading, forcing the reader to spend more time and effort on a segment which should be handy and useful". 
A parallel can be drawn between the observations of the students reading the front matter text of DSS2 and those reading the DSSyn regarding the complexity of syntax used. The front matter text of the DSSyn is also syntactically demanding (sentences that are too long and too complex), which is likely to discourage users from reading it before they start to use the dictionary.

\subsubsection{Examples}

Theoretical explanations are exemplified, but - similar to DSS2 - the examples are mostly provided in the form of lemmata and only occasionally in the form of full entries or excerpts from entries. Students generally consider the examples helpful, but make some critical remarks about the typography of examples. They note that examples differ typographically from the explanations, the problem being that some examples are bolded and some italicized (cf. also Farina, Vrbinc and Vrbinc 2019). They find the system of marking the examples in two different ways confusing and suggest the use of the same typography for all examples. Another proposal made by students concerns the consistent inclusion of full entries or at least the relevant part of the entry instead of lemmata. This suggestion is in agreement with that of the students who read the front matter text of DSS2.

\subsubsection{What the students like}

Several students emphasize that the text is visually well-organized, as it is divided into coherent paragraphs that are mostly not too long. The main text is accompanied by keywords printed in red on the left- or right-hand side of the text in an extra column and positioned at the beginning of the corresponding paragraphs. These keywords guide the reader through the text and make it easier for the user to find a particular topic. Instead of reading the entire text, readers can simply look for the appropriate key word(s) and read only those segments they are interested in rather than the whole text.

Two other points are made by students regarding segments of text they find useful. One of these is the section dealing with the use of the synonyms provided in the dictionary, since it explains how synonyms can be incorporated in other contexts. The other one refers to the inclusion of pronunciation accompanying foreign words whose pronunciation is not predictable for native speakers of Slovenian.

\subsubsection{Proposals for improvement of the text}

Apart from some proposals targeting the inclusion and treatment of examples (cf. 4.2.2), one of the main issues addressed by the students concerns the use of (too) many technical terms that are not intelligible to English majors, let alone to average users who are non-linguists. To resolve this, one student who thinks 
that the terms should be explained suggests providing explanations by means of footnotes. In this way, the additional explanations would be excluded from the text proper, thus making the text more readable and understandable. A suggestion made by one student is to have two parallel front matter texts: a simplified version intended for a general user and a more detailed and technical version for "more curious and demanding users", a suggestion echoing a point made by Nielsen (1995: 169).

Students reading the part of the front matter text that explains labels used in the DSSyn seem to dislike the way labels are presented and explained. Labels are grouped according to categories expressing diasystematic information, which poses problems to an average user unfamiliar with the existence of the theoretical classification of labels. Not being familiar with the classification of labels, it is next to impossible for the user to locate a label he/she is trying to find. To settle this issue, students suggest listing the labels in a table of labels and arranging them alphabetically, together with appropriate examples in the form of entries.

Students frequently refer to the problem of the length of the text and point out that there is plenty of material in the front matter that could easily be omitted without detriment to users. Generally, they like the structure of the text with its subdivision into sections and subsections, as well as good examples illustrating the theoretical explanations. Nevertheless, they think the text is difficult to read and consequently not comprehensible to the average reader. Most of the information provided is relevant and useful for users of this dictionary, but under one condition only: If they manage to understand the point made in a particular part of the text. Their common observation is that, as far as the text is concerned, "much can be done to improve its intelligibility". Given the unintelligibility and length of the text, several students would stop reading it as soon as they found the part that would help them to use the dictionary. To improve access to and retrieval of information needed, one student suggests that it would be useful to have "an index of a certain kind that would enable the user to find the necessary information quickly". Several students agree that the text has several superfluous paragraphs: e.g., the origins of synonymy and sources used for the compilation of the dictionary, since "on the entire page and a half, they only mention the DSS as their source and material".

One student makes an interesting remark about the entire text: "It seems like a textbook (e.g., a list of types of synonyms) rather than a dictionary. While reading the text, one has the impression that they have to remember all the details as if they were going to be examined at school the next day".

\subsection{Dictionary of Legal Terminology}

\subsubsection{Terminology and syntax}

With the exception of some terms (e.g., kodificirati 'codify', tezaver 'thesaurus', ekscerptor 'excerptor') that are not explained and would therefore constitute 
quite a challenge to some users, terminology used in the front matter text is not too difficult to comprehend. Students, however, critically observe that if terms are used, they are not all equally well-defined. They list legal terms lacking explanations (e.g., sodna praksa 'case law'; običajno pravo 'customary law'; kanonsko pravo 'canon law'; pravna doktrina 'legal doctrine') as well as terms that they find adequately explained (e.g., terminološki dogovor 'terminological agreement'). Since the dictionary is primarily intended for (semi-)experts in law and for laypeople interested in this subject field, the legal terminology used in the front matter text "needs no explanation".

Regarding syntax, students reading the front matter text in the DLT come to the same conclusion as their peers reading the front matter texts in DSS2 and DSSyn: The syntax is difficult, the main problem being the length of sentences which are "hard for a reader to follow". One student notes that on several occasions, the authors of this front matter use "incredibly convoluted syntactic structures to form sentences".

\subsubsection{What the students like}

The students mostly like the structure of the front matter text, which is divided into sections and subsections enabling readers to focus on the specific item of information they need. The division of the text is a useful feature, since an average user is unlikely to read the front matter text from beginning to end.

Students note that the exact number of lemmata included and treated in the dictionary is provided (i.e., 10,094 lemmata), a piece of information they really find interesting, since it is rarely encountered in general dictionaries nowadays. Other interesting features identified by the students are as follows: a clear explanation of the type of dictionary; a detailed list of areas of law from which the legal terms included in the dictionary are taken; and the list of sources (printed and electronic ones, dictionaries and parallel corpora as well as terminological databases) with Slovenian legal terminology.

\subsubsection{Proposals for improvement of the text}

The section About the Compilation of the Dictionary includes a list of people who contributed to the dictionary; it occupies as many as one and a half pages. Students believe that most people reading the front matter would simply not bother reading the names, so the names of contributors would "go unnoticed". They suggest moving the list of contributors either somewhere else in the front matter or even to the back matter, since it interrupts the flow of the text describing how the dictionary was compiled.

Overall, students consider the text interesting, though probably too detailed for an average user. They agree that there is nothing wrong with the length of the text as long as it is organized clearly and divided into sections. As opposed to some students who like the structure of the text (see 4.3.2), one stu- 
dent suggests that the user would benefit more if the front matter text was organized more clearly and divided into more sections. The same student also proposes that paragraphs should be broken into shorter ones (some paragraphs extend over half a page), since this, combined with more sections, would contribute to improved readability of the text. One of the students nicely summarizes the problem of length and TMI as follows: "The text - albeit relatively lengthy - offers thorough explanations of every constituent part of the dictionary. What it lacks in compactness, it makes up for in attention to detail."

\section{Discussion and conclusion}

Students commenting on the same front matter text and even on the same segment of the front matter text often express contradictory views on the use of terminology. All agree that the texts abound in linguistic terms most users would not understand. It is, however, interesting to note that some students say that all or most of the terms are explained, while others claim terms are not explained at all. There may be several explanations for these contradictory claims. Some students may simply ignore the explanations provided, or terms are explained in other segments of the front matter text they were not supposed to read. Prior to their task, students were warned about this and were told to try to find unknown terms in the previous parts of the text. The most likely reason, however, is that they could not remember the explanations for such a great number of terms used in the text and believed that they had not previously come across a specific term, when in fact, the term had been explained earlier in the text.

Students reading the front matter text in the DLT generally agree that terminology is not abundantly used and, if it is, the terms are explained. In DSS2 and DSSyn, however, the abundant use of terminology is one of the greatest challenges faced by any reader of the texts. This problem affects not only the average dictionary user but even the tiny minority of users with linguistic education. One student who clearly expresses his/her dissatisfaction with the comprehensibility of the text claims that a reader of the text should have at least a BA in Slovenian to fully comprehend the text. Interestingly, another student who also had comprehension problems went one step further and asked his/her friend who has a BA in Slovenian and who is currently an MA student of Slovenian whether he/she was familiar with the terms used in the segment of the text dealing with accent (tonemic accent, dynamic accent, etc.) and his/her colleague responded it was the first time he/she had ever heard of them. $\mathrm{He} / \mathrm{She}$ concludes that, if the front matter text is intended neither for a general user nor for an expert, the question remains: Who is it actually for?

The length of the front matter texts studied is also a problem commented upon by a number of students, including those reading the front matter text in the DLT, the shortest front matter text of all three dictionaries. Our students often say that they would never have read the front matter if it had not been for 
an assignment because it is too long, and one of them concludes with resignation: "No wonder no one bothers to read the front matter". Obviously, users want to find the necessary information immediately and not wade through information of no interest; in other words, they do not want TMI. One conclusion that can be drawn from the students' criticism is that lexicographers should consider including only the essential information in the front matter text - all texts that are not absolutely necessary should either be omitted altogether or placed separately and not as part of the user guide. As Varantola (2003: 233) admirably puts it, "user instructions are hands-on sections that should be highly sensitive of user behaviour and strategies and thus be written with the user's 'discovery procedure' in mind".

Without a shadow of a doubt, the front matter texts in DSS2 and DSSyn in particular were not written with a user in mind - they were written for an expert in linguistics or possibly even for the compilers themselves! This is in line with Varantola (2003: 233), who explicitly states that "[w]hat is often wrong about the user manual sections in dictionaries is that they are written from the compiler's point of view". Nielsen (2006: 10) points out that it is difficult to know whether the reason behind the user's failure to read the front matter is "directly linked to their perception of the quality and information value of those texts seen from the user's point of view". He goes on by saying that, if users believe the texts are of low quality and consequently decide not to waste time reading them, the texts "do not serve any purpose". In our case, we definitely cannot say that the texts are poorly written - on the contrary, as many of our students observe, the texts are precise, informative and well written, but, unfortunately, far too difficult for an average user to understand. So Nielsen's claim about such texts not serving any purpose certainly applies to the front matter texts in the three dictionaries studied, especially to those in DSS2 and DSSyn. As has already been pointed out in Section 1, the sender of the user guide is the lexicographer and the receiver is the user. We cannot but agree with Nielsen (2006: 10), who says that "it is important that lexicographers keep this in mind when they write the user guide so that they do not produce a text that looks as if it has been written for their own benefit or that of their academic colleagues, but instead a text that appears to have been written for the benefit of the reader/user". The user reading the front matter text cannot pose questions to the lexicographers who wrote the text, which means that these texts are clearly an example of one-way communication (Nielsen 2005: 141; Nielsen 2006: 10).

Interestingly, if we focus on the style of writing used in the front matter texts under consideration, we clearly notice that the texts are written as a comprehensive description of individual information categories rather than providing information directly to the user. In no part of the texts studied do lexicographers address the user personally by using the second person, which is "a clear signal to the user that the text is addressed to him or her" (Nielsen 2006: 17). Nielsen's recommendation is completely ignored in the front matter texts 
under consideration.

One of the positive features identified and highlighted by the students is the systematic nature of all the front matter texts they read. In particular, they refer to the neat arrangement of material in numbered paragraphs in DSS2 and the use of the red keywords in the special column in the DSSyn. In this way, the lexicographers have the possibility to make cross-references to other paragraphs, since the inclusion of cross-references whenever relevant assists use and understanding. For the users, it is easy to follow the cross-references and find the specific place referred to.

Another issue that needs to be addressed is that none of the front matter texts under consideration includes a graphic presentation of the entry (the only exception being the graphic presentation of a single entry in the DSSyn; cf. also 2.2), an element that is almost a must if we are to visually convey the structure and layout of the dictionary entry. The graphic presentation of the entry should be accompanied by explanations focusing on various dictionary functions. It is true that a graphic presentation might be "less satisfying linguistically and philosophically", but it definitely "takes significantly less time to absorb than elegant, discursive prose" (Kirkpatrick 1989: 756). Not only would visually oriented users greatly benefit from this, but it is also a way to present different information categories in the most user-friendly way, which enables the users to retrieve the necessary information as quickly as possible. This is why graphic presentation is essential in both printed and online dictionaries.

Our students were forthcoming in explaining the obstacles they faced when confronted with the task of reading the front matter texts and commenting on various aspects of the text. The perceptions of these advanced users English majors - are valuable to those seeking to improve the front matter texts, or more specifically, the user guides within the front matter, in Slovenian dictionaries, as well as those writing user guides of any other dictionary regardless of the language(s) included or treated in the dictionary. While it is definitely a challenge to write a text that sufficiently explains the different aspects of dictionary functions in language that the intended user is likely to understand, we cannot but agree with Nielsen (2005: 145), who says that if lexicographers write user guides perceived by the user as beneficial and necessary, "this may herald a new era for the user's guide".

\section{References}

\section{Dictionaries}

Collins English Dictionary: https://www.collinsdictionary.com/dictionary/english. Accessed on 6 March 2019.

Pravni terminološki slovar (Dictionary of Legal Terminology): https://fran.si/iskanje?Filtered DictionaryIds=211\&View=1\&Query=\%2A. Accessed on 12 February 2019. 
Sinonimni slovar slovenskega jezika (Dictionary of Slovenian Synonyms): https://fran.si/iskanje? FilteredDictionaryIds=208\&View=1\&Query=\%2A. Accessed on 21 February 2019.

Slovar slovenskega knjižnega jezika (Dictionary of Standard Slovenian): https://fran.si/iskanje? FilteredDictionaryIds=133\&View=1\&Query=\%2A. Accessed on 16 January 2019.

\section{Other literature}

Atkins, Beryl T. Sue and Michael Rundell. 2008. The Oxford Guide to Practical Lexicography. Oxford: Oxford University Press.

Bergenholtz, Henning. 2012. What is a Dictionary? Lexikos 22: 20-30.

Bergenholtz, Henning, Sven Tarp and Herbert Ernst Wiegand. 1999. Datendistributionsstrukturen, Makro- und Mikrostrukturen in neueren Fachwörterbüchern. Hoffmann, Lothar, Hartwig Kalverkämper, Herbert Ernst Wiegand, Christian Galinski and Werner Hüllen (Eds.). 1999. Fachsprachen. Ein internationales Handbuch zur Fachsprachenforschung und Terminologiewissenschaft / Languages for Special Purposes. An International Handbook of Special-Language and Terminology Research, Vol. 2: 1762-1832. Berlin/New York: Walter de Gruyter.

Farina, Donna M.T.Cr., Marjeta Vrbinc and Alenka Vrbinc. 2019 [in press]. Problems in Online Dictionary Use for Advanced Slovenian Learners of English. International Journal of Lexicography. doi: 10.1093/ijl/ecz017.

Fuertes-Olivera, Pedro A. and Henning Bergenholtz. 2011. Introduction: The Construction of Internet Dictionaries. Fuertes-Olivera, Pedro A. and Henning Bergenholtz (Eds.). 2011. e-Lexicography: The Internet, Digital Initiatives and Lexicography: 1-16. London/New York: Continuum.

Gouws, Rufus. 2018. A Dynamic Lexicographic Practice for Diverse Users and Changing Technologies. Mesthrie, Rajend and David Bradley (Eds.). 2018. The Dynamics of Language. Plenary and Focus Lectures from the 20th International Congress of Linguists: 231-244. Cape Town/Claremont: UCT Press.

Hartmann, Reinhard Rudolf Karl. 2001. Teaching and Researching Lexicography. Harlow, Essex: Pearson Education.

Hartmann, Reinhard Rudolf Karl and Gregory James. 1998. Dictionary of Lexicography. London/ New York: Routledge.

Kirkpatrick, Betty. 1989. User's Guides in Dictionaries. Hausmann, Franz Josef, Oskar Reichmann, Herbert Ernst Wiegand and Ladislav Zgusta (Eds.). 1989. Wörterbücher, Dictionaries, Dictionnaires. An International Encyclopedia of Lexicography. Volume 1: 754-761. Berlin/New York: Walter de Gruyter.

Klosa, Annette and Rufus H. Gouws. 2015. Outer Features in e-Dictionaries. Lexicographica 31: 142-172.

Landau, Sidney I. 2001. Dictionaries: The Art and Craft of Lexicography. Second edition. Cambridge: Cambridge University Press.

Müller-Spitzer, Carolin. 2013. Textual Structures in Electronic Dictionaries. Gouws, Rufus H., Ulrich Heid, Wolfgang Schweickard and Herbert Ernst Wiegand (Eds.). 2013. Dictionaries. An International Encyclopedia of Lexicography. Supplementary Volume: Recent Developments with Focus on Electronic and Computational Lexicography: 367-381. Berlin: De Gruyter.

Nielsen, Sandro. 1995. Dictionary Components. Bergenholtz, Henning and Sven Tarp (Eds.). 1995. Manual of Specialised Lexicography: 167-187. Amsterdam/Philadelphia: John Benjamins. 
Nielsen, Sandro. 2005. User's Guides. Barz, Irmhild, Henning Bergenholtz and Jarmo Korhonen (Eds.). 2005. Schreiben, Verstehen, Übersetzen, Lernen. Zu ein- und zweisprachigen Wörterbüchern mit Deutsch: 137-146. Frankfurt am Main: Peter Lang.

Nielsen, Sandro. 2006. A Functional Approach to User Guides. Dictionaries: Journal of the Dictionary Society of North America 27: 1-20. doi:10.1353/dic.2006.0006.

Svensén, Bo. 2009. A Handbook of Lexicography: The Theory and Practice of Dictionary-Making. Cambridge: Cambridge University Press.

Varantola, Krista. 2003. Linguistic Corpora (Databases) and the Compilation of Dictionaries. Van Sterkenburg, Piet (Ed.). 2003. A Practical Guide to Lexicography: 228-239. Amsterdam/Philadelphia: John Benjamins. 